\title{
Embryogenic Callus Induction of Arenga pinnata Wurmb Merr. (Sugar palm) from Basal Stem Explant
}

\author{
Nazatul Asikin Muda ${ }^{1}$, Asmah Awal ${ }^{2}$, Mohd Yusoff Abdullah ${ }^{3}$ and Shamsiah Abdullah ${ }^{4}$
}

\begin{abstract}
The present study investigated the induction of embryogenic callus from basal stem explant of sugar palm (Arenga pinnata) obtained from in vitro seedlings. The primary callus induction from basal stem explant was highly dependent on genotype and concentrations of plant growth regulators (PGRs) used. Optimum primary callus induction was determined on MS [1] medium supplemented with 2, 4-Dichlorophenoxyacetic acid (2,4-D) in combination with Kinetin (Kin). Embryogenic calli were obtained on similar medium after 12 weeks incubation. The primary callus induced was in the form of translucent white floss and gradually grown as embryogenic compact callus within 4-8 weeks of culture. The optimum callus induction frequency was recorded at $70 \%$ with the optimum mean diameter of $0.850 \pm 0.17 \mathrm{~cm}$ and mean fresh weight of $0.450 \pm 0.06 \mathrm{~g}$. Embryogenic calli were proliferated in silver nitrate $\left(\mathrm{AgNO}_{3}\right)$ added medium.
\end{abstract}

Keywords - Arenga pinnata, callus induction, embryogenic callus, basal stem explant, plant growth regulators.

\section{INTRODUCTION}

As one of the most influential method for the induction of rapid crop improvement in modern plant breeding, plant tissue culture plays a great role in both agriculture and industry sectors. Recent developments in plant science have clearly shown that biotechnological approach has contributed the most for the improvement of many valuable crop plants which is includes palm species [2, 3 and 4]. Palm species, which belongs to monocotyledonous group tend to have similar propagation limitations of slow propagation via conventional means, limited offshoot production, high degree heterozygosity, dioceous nature [5], inferior quality of seedlings, difficult rooting of offshoots under field condition [6], poor seed germination [7], and time-consuming germination process due to dormancy [8]. In agriculture, these issues can be overcome through plant tissue culture as it offers the included benefits of rapid mass propagation of genetically identical plants production, making clones of slow growing species which are very difficult to propagate by conventional

Manuscript received Dec. 29, 2015. This work was supported in part by research grant 600-RMI/DANA5/3/REI (1/2013) and Mybrain-15 Scholarship, Ministry of Higher Education, Malaysia.

Nazatul Asikin Muda ${ }^{1}$ is with the Agricultural Biotechnology Research Group, Faculty of Plantation and Agrotechnology, UiTM, 40450, Shah Alam, Selangor, Malaysia.

Asmah $\mathrm{Awal}^{2}$ is with the Agricultural Biotechnology Research Group, Faculty of Plantation and Agrotechnology, UiTM, 40450, Shah Alam, Selangor, Malaysia.

Mohd Yusoff Abdullah ${ }^{3}$ is with the Faculty of Plantation and Agrotechnology, UiTM, 40450, Shah Alam, Selangor, Malaysia. Shamsiah Abdullah ${ }^{4}$ is with the Faculty of Plantation and Agrotechnology, UiTM, 40450, Shah Alam, Selangor, Malaysia. means, all year round production within a limited production space and maintenance and large scale propagation through somatic embryogenesis [9].

Meanwhile in breeding work, plant tissue culture is mainly useful for the maintenance and multiplication of elite genotypes and new cultivars. Plants produced through the method are true-to-type and often show improved potency and quality [10]. However, plant tissue culture is at disadvantages by the limitations of skilled workers requirement, high costing laboratory investment and maintenance. Loss of valuable micropropagated plants is also relatively high during the process of acclimatization and transfer to field [9]. As a first step in many plant tissue culture studies, the induction of callus formation from the primary explant is essential. This explant may derive of aseptically germinated seedling or surface-sterilized reproductive structures or organs such as roots, stem and leaves. Callus is the proliferated cells produced in response to injury of explant. It is generally made up of friable, large, vacuolated cells that are highly differentiated and unorganized. Callus structures can be hard and compact, and can contain regions of small merismetic cell clusters [11].

Theoretically, all plants are totipotent if suitably stimulated, and the meristematic cells are best able to express it, usually in term of shoot or root development. However, not all cells in an explant can contribute to the formation of callus as only a certain callus cell types are capable to regenerate organized structures [11]. The major factor that controls the formation of callus is the level of plant growth contained in culture medium. For each plant species, the concentrations of PGRs may vary and can even depend on the source of explants or individual plant genotype, age, nutritional status and etc. Culture conditions such as temperature, culture media and light condition are also crucial for callus formation and development [11].

Once established, the callus can be used for variety of experiments such as somatic embryogenesis, organogenesis, protoplast isolation, cell type, cellular selection and secondary product production. Additionally, regenerable callus is useful as a target for genetic transformation technology which responsible for the production of improved crop varieties, production of disease-free plants, production of secondary metabolites, production of varieties tolerant to salinity, drought and heat stresses and genetic transformation study which are responsible in the production of improved crop variety, production of disease-free plants [12].

Sugar palm is the perennial monocotyledonous tree which is classified in family Arecaceae. It is well known in Malaysia as 'kabung'. In other regions sugar palm is also commonly name as areng palm, black fiber palm, aren and toddy palm. Sugar 
palm in its native range is also found growing in some forested areas but never far from settled areas as in ravines, along streams, on slopes and areas under semi-cultivation. It is also occasionally found in virgin forests since its fruits are scattered by fruit bats, wild pigs, civet cat and probably small mammals [13]. It can grow and survives in most of soils conditions and improving the ecosystems of forest floors [14]. Sugar palm is economically cultivated for its sugary sap, fibres, biofuel, and several other minor uses $[15,16]$.

The norm of sugar palm is not restricted for consumable and industrial products only. In term of natural conservation services, sugar palm trees serves as erosion preventer [17]. Sugar palm cultivation also helps in the improvement of soil macro conditions, soil porosity, and trapping rainwater [18]. This palm species in its traditional propagation method are difficult due to seed dormancy, limited offshoot production, slow fruit development and slow seed germination [19]. However, the prospect of utilizing sugar palm for economic purpose requires rapid propagation, which is made possible via micropropagation through tissue culture. Propagation of sugar palm via conventional way may take years to optimized germination. Callus culture of sugar palm has been carried out previously using zygotic embryos [18] and shoot tip explants [20] but none reported from basal stem explant to our knowledge.

The present study described the optimum embryogenic callus induction protocol from basal stem explant of sugar palm derived from in vitro seedlings in the effect of plant growth regulators at different concentrations and combinations.

\section{MATERIALS AND METHODS}

\section{A. Preparation of Plant Materials}

Dissected zygotic embryos obtained from surfaced sterilized fresh fruits were cultured on MS0 media to obtained in vitro seedlings for the source of explants. In vitro seedlings at an approximate height of 4.0-7.0 cm were separated into different sections (Fig. 1a). Basal stem explant was taken for embryogenic callus induction experiment.

\section{B. Callus Induction and Maintenance}

Single basal stem explant at an approximate size of $1.0 \mathrm{~cm}$ was cultured horizontally on semi-solid MS medium containing $30.0 \mathrm{~g} / \mathrm{L}$ sucrose, $2.5 \mathrm{~g} / \mathrm{L}$ gelrite and various concentrations of 2,4-D (0.1-0.5 mg/L) and Kin (0.5 and 1.0 $\mathrm{mg} / \mathrm{L}$ ) at any possible combinations. All culture media were adjusted to pH 5.8 prior to autoclaving for 20 minutes at $121^{\circ} \mathrm{C}$. Cultures were then incubated under complete darkness at the temperature of $25 \pm 2^{\circ} \mathrm{C}$. Subcultures were carried out at 4 weeks interval throughout the culture process.

\section{Statistical Analysis}

Callus culture experiment of sugar palm was arranged in Randomized Completely Block Design (RCBD). Each treatment was replicated ten times with a single explant for each vial. The callus induction frequency (\%), mean callus fresh weight $(\mathrm{g} \pm \mathrm{SE})$ and mean callus diameter $(\mathrm{cm} \pm \mathrm{SE})$ were monitored as growth parameters (Table 1).

\section{RESULTS}

\section{A. Callus Induction}

Callus culture was successfully established from basal stem explant of sugar palm cultured on MS induction medium supplemented with 2 , 4-D $(0.1-0.5 \mathrm{mg} / \mathrm{L})$ in combination to $0.5-1.0 \mathrm{mg} / \mathrm{L}$ BAP (Table 1). Different response in callus initiation was exhibited from the treatments. Lower combination ratios of 2, 4-D and Kin was found to give significantly better callus formation instead of higher concentrations. At $0.2 \mathrm{mg} / \mathrm{L} 2,4-\mathrm{D}+0.5 \mathrm{mg} / \mathrm{L}$ Kin, explant showed optimum frequency $(70 \%)$ of embryogenic calli within 8 weeks of culture, with optimum mean fresh weight of $0.450 \pm 0.06 \mathrm{~g}$ and mean diameter of $0.850 \pm 0.17 \mathrm{~cm}$.

It was noticed that medium containing $0.4-0.5 \mathrm{mg} / \mathrm{L} 2,4-\mathrm{D}$ combined with both 0.5 and $1.0 \mathrm{mg} / \mathrm{L}$ Kin showed the least explant response. Therefore, it is determined that 2, 4-D act as an important hormone for callus initiation and that its concentrations plays an important role in the development of embryogenic callus. Early development of callus tissues was in form of elongated and translucent white floss (Fig. 1b), which gradually developed into beige compact structure within 7-8 weeks of incubation (Fig. 1c). Calli were found to form from the wound region. Proliferated embryogenic calli were formed when transferred on MS media supplemented with $\mathrm{AgNO}_{3}$ (Fig. 1d).

\section{Discussion}

The effect of 2, 4-D in combination with Kin plant hormones was examined on basal stem explant of sugar palm to determine the induction of embryogenic competence (callus). Explants response and different concentrations and combinations of PGRs to embryogenic callus formation in palm species was previously reported by [21, 22].

In the current research, basal stem explant inoculated on MS medium supplemented with lower concentrations of PGRs $(0.2 \mathrm{mg} / \mathrm{L} 2,4-\mathrm{D}+0.5 \mathrm{mg} / \mathrm{L}$ Kin $)$ gave better response to callus formation. Similar response was reported by [23] to the induction of maximum callus at $89 \%$ in contribution of lower concentrations of auxin 2, 4-D and picloram on oil palm. However, our result was contradicted to [24] whom reported the application of higher concentrations of PGRs to initiate callus from young leaf explant of tenera palm.

TABLE I: THE ESTABLISHMENT OF EMBRYOGENIC CALLUS ON BASAL STEM EXPLANT OF SUGAR PALM AFTER 8 WEEKS OF CULTURE

\begin{tabular}{|c|c|c|c|c|c|}
\hline \multirow{2}{*}{ Treatment } & \multicolumn{2}{|c|}{$\begin{array}{l}\text { Composition } \\
(\mathrm{mg} / \mathrm{L})\end{array}$} & \multirow{2}{*}{$\begin{array}{c}\text { Callus } \\
\text { Induction } \\
\text { Frequency } \\
(\%)\end{array}$} & \multirow{2}{*}{$\begin{array}{l}\text { Callus fresh } \\
\text { weight } \\
(\mathrm{g} \pm \mathrm{SE})\end{array}$} & \multirow{2}{*}{$\begin{array}{c}\text { Callus } \\
\text { diameter } \\
(\mathrm{cm} \pm \mathrm{SE})\end{array}$} \\
\hline & 2,4-D & KIN & & & \\
\hline A1 & 0.1 & 0.5 & 60 & $0.200 \pm 0.08$ & $0.500 \pm 0.12$ \\
\hline A2 & 0.2 & 0.5 & 70 & $0.450 \pm 0.06$ & $0.850 \pm 0.17$ \\
\hline A3 & 0.3 & 0.5 & 50 & $0.075 \pm 0.01$ & $0.500 \pm 0.12$ \\
\hline A4 & 0.4 & 0.5 & Nil & Nil & Nil \\
\hline A5 & 0.5 & 0.5 & Nil & Nil & Nil \\
\hline A6 & 0.1 & 1.0 & 70 & $0.300 \pm 0.00$ & $0.400 \pm 0.00$ \\
\hline A7 & 0.2 & 1.0 & Nil & Nil & Nil \\
\hline A8 & 0.3 & 1.0 & Nil & Nil & Nil \\
\hline A9 & 0.4 & 1.0 & 70 & $0.075 \pm 0.03$ & $0.225 \pm 0.09$ \\
\hline A10 & 0.5 & 1.0 & Nil & Nil & Nil \\
\hline
\end{tabular}

Note: Each callus induction frequency (\%), mean callus fresh weight (g士SE) and mean callus diameter $(\mathrm{cm} \pm \mathrm{SE})$ values are the result of ten replications from a single experiment. 

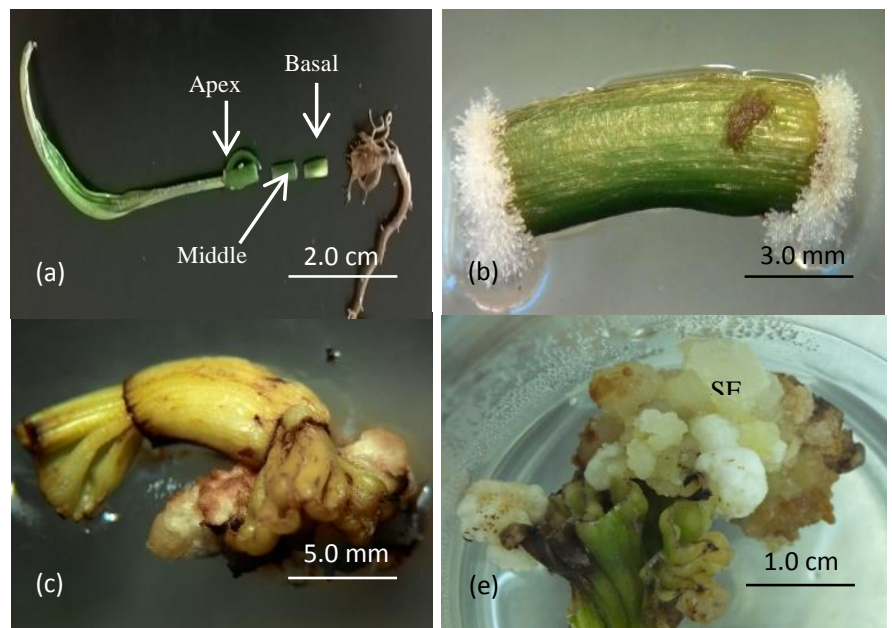

Fig. 1. Callus induction system of sugar palm from basal stem explant (a) separated single basal stem explant from 10 month old in vitro seedling [b] induction of friable white floss callus after 4 weeks of culture (c) compact primary callus induction after 8 weeks of culture in optimum culture medium consisted of $0.3 \mathrm{mg} / \mathrm{L} 2,4-\mathrm{D}+0.5 \mathrm{mg} / \mathrm{L}$ Kin (d) embryogenic callus on proliferation media after 3 months of culture.

\section{Conclusion}

To summarize, embryogenic callus has been achieved in sugar palm, firstly reported from basal stem explant extracted from in vitro seedlings of sugar palm. It was concluded from the present investigation that the optimum embryogenic callus induction was successfully established on low concentrations of 2 , 4-D $(0.2 \mathrm{mg} / \mathrm{L})$ in combination to $\mathrm{Kin}(0.5 \mathrm{mg} / \mathrm{L})$. Further research protocol is needed to investigate somatic embryogenesis and plant regeneration of sugar palm.

\section{ACKNOWLEDGEMENT}

The authors gratefully acknowledge the support of this research by research grant 600-RMI/DANA5/3/REI (1/2013) and Frgs/1/2013/STWN03/UITM/02/3, Universiti Teknologi MARA (UiTM) Shah Alam, Malaysia and Mybrain15 scholarship, Ministry of Higher Education, Malaysia.

\section{REFERENCES}

[1] T. Murashige and F. Skoog, "A Revised Medium for Rapid Growth and Bioassays with Tobacco Tissue Cultures," Physiologia Plantatrum, Vol. 15, pp. 473-497, 1962. http://dx.doi.org/10.1111/j.1399-3054.1962.tb08052.x

[2] A. Thuzar, S. Vanavichit, S. Tragoonrung, and C. Jantasuriyarat. "Recloning of Regenerated Plantlets from Elite Oil Palm (Elaies guinensis Jacq.) cv. Tenera," African Journal of Biotechnology, Vol. 11(82), pp. 14761-14770, 2012.

[3] S.M. Khierallah and M.S. Bader, "Micropropagation of Date Palm (Phoenix dactylifera L.) Var. Maktoom through Direct Organogenesis," Proc. IIIrd IC on Date Palm, Eds: A. Zaid et al. pp. 213 - 224, Acta Hort 736, ISHS, 2007. http://dx.doi.org/10.17660/actahortic.2007.736.19

[4] E.M. Graner, G.P.J. Oberschelp, G.E. Brondani, K.D. Batagin-Piotto, C.V. Almeida and M. Almeida. (April 2013). TDZ pulsing evaluation on the in vitro morphogenesis of peach palm. Physiol Mol Biol Plants. [Online]. $19 \quad$ (2). $\quad$ pp. 283-288. Available: http://www.ncbi.nlm.nih.gov/pmc/articles/PMC3656191. http://dx.doi.org/10.1007/s12298-012-0160-4

[5] S.A. Bekheet, "In vitro conservation of date palm germsplasm," in Date Palm Biotechnology, S.M. Jain, J.M. Al-Khayri and D.V. Johnson, Eds. New York: Springer, 2011, pp. 350-354.

[6] S.S. Kurup, M.A.M. Aly, G. Lekshmi and N.H. Tawfik, "Rapid in vitro regeneration of date palm (Phoenix dactylifera $\mathrm{L}$.) cv. Kheneizi using tender leaf explant," Emir. J. Food Agric., Vol. 26(6), pp. 539-544, 2014.

http://dx.doi.org/10.9755/ejfa.v26i6.18051

[7] K. Kanchanapoom, A. Phongdara, and K. Kanchanapoom. (2010). The Effect of Chitosan on the Organogenesis of Oil Palm Embryo-Derived Callus. Notulae Botanice Horti Agrobotanici Cluj-Napoca. [Online] 38 (1), pp. 213-217. Available: http://www.notulaebotanicae.ro

[8] M.S. Padua, L. Paiva, C.R.G. Labory, E. Alves, and V.C. Stein. (2013). Induction and Characterization of Oil Palm (Elaeis guineensis Jacq.) Pro-Embryogenic Masses. Anais da Academia Brasileira de Ciências. [Online]. 85 (4), pp. 1545-1556. Available: http://www.scielo.br. http://dx.doi.org/10.1590/0001-37652013107912

[9] T. B. Jha, and B. Ghosh, Plant Tissue Culture: Basic and Applied, India: University Press, 2005, pp. 45-50, ISBN 8173714886. [5]

[10] S. Bekheet, "Direct Organogenesis of Date Palm (Phoenix dactylifera L.) for Propagation of True-to-Type Plants," Sci. Agri., vol. 4(3), pp. 8592, 2013.

[11] R.H. Smith, Plant Tissue Culture: Techniques and Experiments. $3^{\text {rd }}$ ed. U.S.A.: Elsivier, Academic Press, 2013, ch. 6, pp. 63-76. http://dx.doi.org/10.1016/B978-0-12-415920-4.00006-2

[12] A. Hussain, I. A. Qarshi, H. Nazir, and I. Ullah, Plant Tissue Culture: Current Status and Opportunities, Pakistan: Intech, 2012, pp. 4-5.

[13] H.B. Florido and P.B. De Mesa, "Sugar Palm [Arenga pinnata (Wurmb) Merr.]," Research Inform. Series on Ecos., vol. 15 (2), pp. 2-6, 2003.

[14] E. Martini, J.M. Roshetko, M.V, A. Rahmanullah, E. Mulyoutami, L. Joshi and S. Budidarsono, "Sugar palm (Arenga pinnata (Wurmb) Merr.) For livelihoods and biodiversity conservation in the orangutan habitat of Batang Toru, North Sumatra, Indonesia: mixed prospects for domestication," World Agroforestry Centre (ICRAF), Jl. CIFOR, 2010.

[15] M.R. Ishak, S.M. Sapuan, Z. Leman, M.Z. Rahman, U.M. Anwar and J.P. Siregar, "Sugar Palm (Arenga pinnata): Its fibers, Polymers and Composites," Carbohydr Polym., vol. 16(9), pp. 699-710, 2013. http://dx.doi.org/10.1016/j.carbpol.2012.07.073

[16] H.Y. Sastra, J.P. Siregar, S.M. Sapuan and M.M. Hamdan, "Tensile properties of Arenga pinnata fiber-reinforced epoxy composites," Polym Plastics Technol Eng., vol. 45 (1-3), pp. 149-155, 2006. http://dx.doi.org/10.1080/03602550500374038

[17] S. Soeseno, Bertanam Aren. Jakarta (ID): Penebar Swadaya, 2000.

[18] M. G. Devi, A. Purwito and A. Husni. (2014). Globular Embryo Induction of sugar palm (Arenga pinnata (Wurmb) Merr.). Int. J. Bio. Sc., Bio Chem., Bio Inf. [Online]. 4(1), pp. 60-66. Available: http://www.ijbbb.org/papers/311-CB044.pdf http://dx.doi.org/10.7763/ijbbb.2014.v4.311

[19] J. Janick and R. E. Paull, The Encyclopedia of Fruit and Nuts, United Kingdom: Cambridge University Press, 2005, pp. 45-50.

[20] R. Putih, B. Satria, and Thaib, R. (2003).Vegetative Propagation Effort of Enau (Arenga pinnata (Wurmb) Merr.) by Shoot Regeneration In Vitro. Stigma [Online]. 11(3), pp. 208-212. Available: http://repository.unand.ac.id/2521/1/Benny-enau.doc

[21] H. Rashid and A. Quraishi, "Micropropagation of date palm through tissue culture," Pakistan J. Agric. Res., vol. 15 (1), pp. 2-7, 1994.

[22] J. Chen and W. Chang, "TIBA effects the induction of direct somatic embryogenesis from leaf explants of Oncidium," Plant Cell Tiss. Org. Cult., Vol. 79, pp. 315-320, 2004 http://dx.doi.org/10.1007/s11240-004-4613-5

[23] M. Jayanthi, B. Susanthi, N.M. Mohan and P.K. Mandal. (June 2015). In vitro somatic embryogenesis and plantlet regeneration from immature male inflorescence of adult dura and tenera palms of Elaeis guineensis (Jacq.). Springerplus. [Online]. 4, pp. 256. Available: http://www.springerplus.com/content/4/1/256. http://dx.doi.org/10.1186/s40064-015-1025-4

[24] M. Constantin, W. A. Nchul, N.N. Godswill, N.M.A. Wiendi, A. Wachjar and N.E.G. Frank. (July-August 2015). Induction of oil palm (Elaeis guineensis Jacq. var. Tenera) callogenesis and somatic embryogenesis from young leaf explants. Journal of Applied Biology \& Biotechnology. [Online]. 3(4). Pp. 4-10. Available: http://www.jabonline.in http://dx.doi.org/10.7324/JABB.2015.3402 


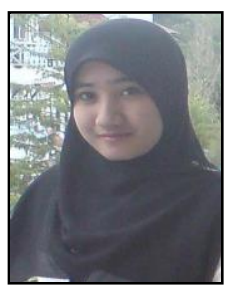

Nazatul Asikin Muda was born in Terengganu, Malaysia in 1987. She had graduated in BSc (Plantation Industry Management) in 2010 from the Faculty of Applied Sciences, UiTM, Shah Alam, Malaysia and MSc (Plantation Industry Management) in 2013 from the Faculty of Plantation and Agrotechnology, UiTM Shah Alam, Malaysia. She is currently pursuing her $\mathrm{PhD}$ in Plant Biotechnology at the same institution and is being sponsored by the Mybrain 15 scholarship under the Ministry of Higher Education Malaysia. During her study, she had worked as research assistant from 2011-2014 and awarded with fellowship from 2010-2013.

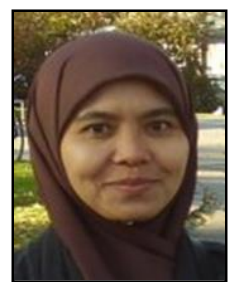

Asmah Awal has obtained her Diploma in Science from Institut Teknologi MARA (ITM) in year 1990, BSc in Botany (1994), MSc in Educational Technology (2001) and $\mathrm{PhD}$ in Plant Biotechnology (2010) at Universiti Malaya, Malaysia. She is currently working as a senior lecturer and Deputy Dean of Academic Affairs at the Faculty of Plantation and Agrotechnology, UiTM Shah Alam, Malaysia. From 2010 to 2014, she had conducted 8 granted research projects. She has many articles published in reputable ISI-cited journals and proceedings. She also had participated in various conferences and exhibitions related to her work.

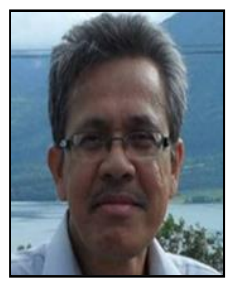

Mohd Yusoff Abdullah has obtained his Diploma in Agriculture from University of Agriculture (UPM) Serdang, Selangor, Malaysia (1974), BS in Botany from University of California, Davis, USA (1977), and MS in Botany-Plant Physiology from University of Wisconsin, Milwaukee, USA in 1979. He then pursued his $\mathrm{PhD}$ in Plant Ecophysiology at University of Cambridge, England in 1994. Currently he works as the principal lecturer at the Faculty of Plantation and Agrotechnology, UiTM Shah Alam, Malaysia. He has published numbers of articles in many reputable ISI-cited journals and proceedings.

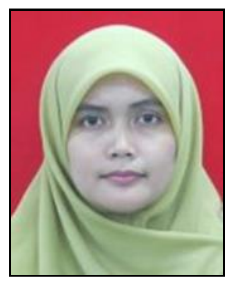

Shamsiah Abdullah has obtained her BSc (Industrial Biotechnology) and MSc at Universiti Malaya in 1999 and 2004 respectively. She then pursued her $\mathrm{PhD}$ in Genetic at Universiti Kebangsaan Malaysia in 2010. She has acted as principal researcher and co-researcher for 7 granted research projects from 2009-2014. She is currently working as a senior lecturer and holds the position as the Coordinator of Postgraduate Coursework Program at the Faculty of Plantation and Agrotechnology, UiTM Shah Alam, Malaysia. 